\title{
WestVirginiaUniversity。
}

Department of Economics

Working Paper Series

\section{The Efficient Corruption Hypothesis and the Dynamics between Economic Freedom, Corruption, and National Income}

Joshua Hall

John Levendis

Working Paper No. 17-06

This paper can be found at the College of Business and Economics Working Paper Series homepage: 


\title{
The Efficient Corruption Hypothesis and the Dynamics between Economic Freedom, Corruption, and National Income
}

\author{
Joshua Hall \\ Associate Professor of Economics \\ Department of Economics \\ West Virginia University \\ joshua.hall@mail.wvu.edu \\ and \\ John Levendis \\ Dr. John V. Connor Professor of Economics and Finance \\ Department of Economics \\ Loyola University New Orleans \\ jlevendi@loyno.edu
}

March 2017

\begin{abstract}
Income, economic freedom, and corruption interact in complex ways as all three variables are arguably endogenous. We explicitly model this endogeneity using a panel VAR framework. The pVAR models we estimate are able to explicitly model this endogeneity better than the single-equation panel data models previously used in the literature. Using data on corruption and income from the World Bank and economic freedom from the Fraser Institute, we provide evidence that corruption and the absence of economic freedom have a negative effect on national income.
\end{abstract}

Keywords: corruption; regulation; institutions; economic freedom

JEL Codes: D73; 043 


\title{
The Efficient Corruption Hypothesis, and the Dynamics between Economic Freedom, Corruption, and National Income
}

\begin{abstract}
"In terms of economic growth, the only thing worse than a society with a rigid, over-centralized, dishonest bureaucracy is one with a rigid, over-centralized, honest bureaucracy” (Huntington, 1968, p.386).
\end{abstract}

\section{Introduction}

Economists and political scientists seem endlessly fascinated by the relationship between corruption and economic performance (Shleifer and Vishny, 1993; Mauro, 1995; Campos, 1999; Bologna, 2016). The earliest thinking was that a well-functioning economy relied on proper institutions. Corrupt bureaucrats personified inefficient institutions. The bribes they demanded were seen as an unnecessary tax on businesses, which would invariably cause distortions, deadweight loss, inefficiency, and poverty.

That thinking was turned on its head in the 1960s, primarily by Leff (1964) and Huntington (1968), who argued that corruption - in some circumstances - provided a muchneeded safety valve from stifling bureaucracy. In such circumstances, corruption "greased the wheels” of commerce by greasing the palms of corrupt officials. This line of thought was revived more recently in the work of Shleifer and Vishny (1993) and Mauro (1995). The common thread in most modern corruption research is that corruption may be beneficial-as a second best-when red tape and regulation is high. Another way of putting it is that corruption might improve upon the state of affairs when there is little economic freedom in a country. ${ }^{1}$

\footnotetext{
${ }^{1}$ Economic freedom is certainly multi-dimensional and more than just bureaucracy (Bologna and Hall, 2014; Gwartney et al. 2016). However, the majority of economic freedom areas (property rights, rule of law, freedom to trade, regulations) are highly correlated (Beaulier et al. 2016).
} 
Research on the relationship between corruption, national income/growth and economic freedom can be categorized as follows:

(1) Does economic freedom or national income affect corruption?

(2) Does corruption or national income affect economic freedom?

(3) Does economic freedom or corruption affect national income?

Figure 1: The relationship between corruption, economic freedom, and growth

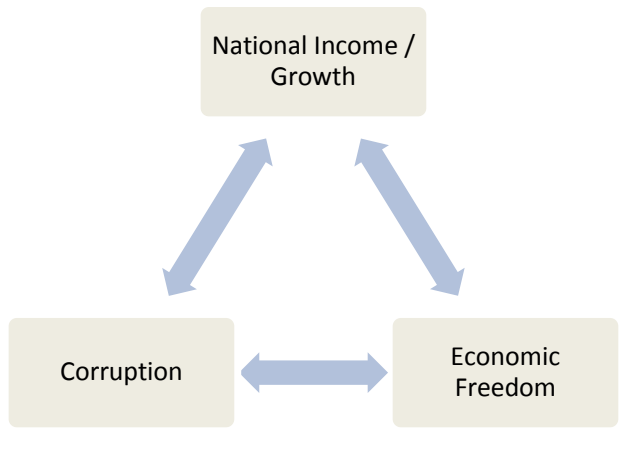

Taken together, it seems as though everyone acknowledges that freedom, corruption, and income are jointly determined as depicted in Figure 1. And yet, to our knowledge no one has investigated all of the endogenous connections between them. Our purpose in this paper is to fill this research gap by using a panel VAR framework to answer all of these questions simultaneously.

The remainder of the paper is organized as follows. First, we provide a brief review of the literature, paying special attention to the three questions above. Then describe our data, before estimating a fully endogenous model of the dynamics between economic freedom, corruption, and income. Finally, we investigate a set of panel-data models that focus on question three, paying special attention to the hypothesis that corruption acts as a safety valve from overregulation. We close with a summary of the findings. 


\section{Literature review}

Why are some countries so riddled with corruption? Do corrupt actors have so much to gain with so little to lose? Does a poor economy provide fertile ground for corruption? Or does corruption flourish according to the institutional setting in which it is planted? Does corruption find a place to hind, and indeed thrive, among the overgrown weeds of bureaucracy? Does corruption plant its own seeds, so that it is self-perpetuating?

There is a large empirical and theoretical literature on corruption trying to answer these questions. Banerjee et al. (2013) provide a good overview of this literature as well as a theoretical model where corruption is determined by the costs and benefits of corruption. For our purposes, we are most interested in the literature on how economic freedom (institutions) affect corruption. For example, Saha et al. (2009) find that economic freedom and democracy generally provide enough sunshine to combat corruption. However, democracy may increase corruption if a country is currently highly regulated. Pieroni and d'Agostino (2013) investigated whether the institutional environment, specifically economic freedom, is inversely correlated with corruption. They find that "market competition may be bad for corruption when institutions are weak, as they often are in developing countries although, in general, the aggregate index confirms that competition reduces corruption... A lack of government regulations may actually yield more corruption in less developed countries, whereas standard recipes for greater freedom can be applied in developed countries” (Pieroni and d'Agostino, p. 70).

A number of other empirical papers also explore economic freedom's relationship with corruption. Goel and Nelson (2005) consider whether political or economic freedom (or its components) affect corruption, concluding that economic freedom (especially in the monetary realm) is most effective at combating corruption. Graeff and Mehlkop (2003) examine the effect 
of economic freedom and its individual components on corruption. They find that the magnitude of economic freedom's effect on corruption depends upon whether the country is rich or poor. Shen and Williamson (2005) treat EFW as exogenous and find that it decreases corruption, however, they do not consider the alternative causal scenario where corruption might affect economic freedom.

Corruption is but one possible determinant of economic freedom. The question of why some countries are more economically free than others has been a growing area of research in economics. Most of the papers have focused on the relationship between democracy, or democratic transitions, and economic freedom. One of the earliest papers in this area is Dawson (1998), who finds a positive relationship between political freedom and economic freedom. Wu and Davis (1999), however, find not such relationship. A number of recent papers using more years of data do find that political freedom or democratic transitions lead to economic freedom (Vega-Gordillo and Alvarez-Arce, 2003; Aixalá and Fabro, 2009; Rode and Coll, 2012). Hall (2016), however, finds no evidence that democracy has led to institutional convergence across countries.

Moving away from the literature focused primarily on economic freedom, there are a number of important factors that relate to how corruption and income influence aspects of economic freedom. For example, one of the more popular models of regulation is the Environmental Kuznets Curve. Under this hypothesis, as economies grow richer, then begin substituting from increased growth toward more environmental regulations; that is, that environmental quality is a normal good, or a luxury good at higher income levels (Grossman and 
Krueger (1993). ${ }^{2}$ In the economic freedom literature, March et al (2017) do find that higher initial GNI per capita is associated with larger increases in economic freedom.

Regulations that lower economic freedom clearly benefit individuals who attempt to seek rents through corruption. Kurer (1993) developed a theoretical model where the degree of red tape is endogenous to a model of corruption. That is, corrupt public servants will often increase the amount of red tape and inefficiency, so that they can then provide citizens with a convenient escape route-for a fee. Corruption, in this case, causes a decline in economic freedom, and this decline further reduces income over and above the usual costs of rent seeking. Similarly, Kaufmann and Wei (1999) developed a formal model where bureaucracy is endogenously determined with the size of the bribe. The prospect of ill-gotten gains invites the bureaucrat to create additional red tape, so that they might sell a way around the rules. Again, corruption diminishes economic freedom. Bjørnskov (2012) empirically finds that corruption leads to greater barriers to trade, especially when the corruption occurs in an already poor country.

By far the largest literature on corruption relates to how it effects national income or growth. For example, corruption can be bad for growth because of its effect on investment (Mauro, 1995). Meon and Sekkat (2005) find that corruption directly lowers growth in addition to indirectly lowering growth by diminishing investment. Several studies have found that corruption decreases foreign direct investment (Wei, 2000; Cuervo-Cazurra, 2006; and Egger and Winner, 2005.

Murphy et al. (1991) also argue that the prospect of being a wealthy corrupt bureaucrat might entice young entrepreneurial talent from productive to extractive pursuits. Corruption might also exacerbate cash and credit constraints among budding entrepreneurs, thereby

\footnotetext{
${ }^{2}$ The early empirical research supported this theory. However, the literature no finds little evidence for the Environmental Kuznets Curve. See, for example, Harbaugh et al. (2002) and Stern (2004).
} 
misallocating technology and capital (Murphy et al., 1993). In a similar vein, Choi and Thum (2004) present a theoretical model where the threat of corruption changes the incentives facing entrepreneurs to make lasting investments. Instead, they opt for the flexibility of fly-by-night investments. Such investments do not provide for sustained economic growth.

Kaufmann and Wei (1999) develop a formal model where the amount of red tape is endogenously determined with the size of the bribe. Firms find themselves, effectively, in a prisoner's dilemma where bribery is individually rational, yet costly. Endogeneity effectively eliminates the "grease the wheels" hypothesis in their model. Further, they find that those manufacturing firms who bribe have higher costs, in terms of time spent as well as cost-ofcapital, than those who do not bribe. Kaufmann and Wei are strongly in the camp that corruption is inefficient. Fisman and Svensson (2007) provide additional microeconomic evidence at the firm level that suggests increases in bribery payments are correlated with decreased rates of firm growth. Extrapolating to the country level corruption is clearly sand in the wheels of commerce. In a paper closely related to ours, Mo (2001) considers the transmission mechanism through which corruption might affect economic growth. Corruption can affect various factors, which in turn, affect growth. He finds evidence that the corruption's effect on political instability has the most impact on growth, followed by the share of private investment, and human capital. However, Mo does not consider whether the effect of corruption might depend upon the institutional setting of the country. While he controls for political rights, he does not control for economic institutions. Further, by including it additively, his model does not allow institutions to mitigate the effects of corruption. Finally, he does not exploit the panel-nature of the available data. Rather, he estimates using the average values for each country. 
Controlling for economic and political institutions is important given the work of de Vaal and Ebben (2011). They develop a theoretical model where the effect of bureaucratic corruption on growth depends upon economic institutions. Corruption in an inefficient bureaucracy increases efficiency. In an otherwise healthy institutional setting, however, it is an economic bad. According to de Vaal and Ebben (2011, p. 12), “Only when the amount or political stability or property rights protection is above some threshold value, corruption affects these institutions negatively, depressing economic growth. This implies that the institutional framework is important for determining the corruption-growth relationship...”

In all of the literature, the endogeneity of corruption is a widely recognized problem, especially for the efficient corruption hypothesis. In his review of the literature, Bardhan (1997, p. 1323) explains that

"It is usually presumed that a given set of [regulatory] distortions are mitigated or circumvented by the effects of corruption; but quite often these distortions and corruption are caused or at least preserved or aggravated by the same common factors. The distortions are not exogenous to the system and are instead often part of the built-in corrupt practices of [the]...system.”

Svennson (2005, pp.36-7) clearly articulates this point with respect to the efficient corruption hypothesis:

“The proponents of 'efficient corruption'... take the distortions circumvented by the corrupt actions as given. In most cases, distortions and corruption are caused by, or are symptoms of, the same set of underlying factors. As Myrdal (1968) pointed out, corrupt officials may not circumvent distortions, but instead actually cause greater administrative delays to attract more bribes.” 
For this reason, we build toward a fully articulated model where economic institutions measured by economic freedom, corruption, and the economy all interact to determine each other.

\section{Data and a First Look}

To measure corruption, we employ two different measures of corruption from the World Bank’s Control of Corruption dataset. (1) CE, an absolute index of corruption, and (2) $C P$, a country's corruption percentile (i.e. relative ranking). $C E$ gives the country's corruption score in units of a standard normal distribution, i.e. ranging from approximately -2.59 to 2.06 . That is, it is in terms of standard deviations. ${ }^{3}$ Being a percentile, $C P$ ranges from 0 to 100 . While there are other corruption datasets, such as those by Political Risk Service (PRS), the International Country Risk Guide (ICRG), and Transparency International’s Corruption Perceptions Index, these measures of corruption are all highly correlated with each other. This is not surprising given that $C E$ is comprised of data from many sources, including PRS and ICRG. Given the high correlation across measures and the public availability of the World Bank data, we opt to use $C E$ and $C P$ in our analysis.

We also employ the World Bank's national income data $(r G D P p c)$, measured as real GDP per capita in constant 2005 US dollars. Data on economic freedom $(E F W)$ are taken from the Fraser Institute’s Economic Freedom of the World dataset (Gwartney et al. 2016). The EFW index measures the extent to which the policies and institutions of a country are consistent with

\footnotetext{
3 The Control of Corruption dataset is part of the World Bank's Worldwide Governance Indicators. According to their documentation, "Control of corruption captures perceptions of the extent to which public power is exercised for private gain, including both petty and grand forms of corruption, as well as 'capture' of the state by elites and private interests (Worldwide Governance Indicators, 2017).”As an index, their data is compiled from a number of sources. Interested readers should see the full documentation available on the WGI site.
} 
economic freedom. ${ }^{4}$ Chain-linked and unadjusted data were available. We used the unadjusted numbers from 2002-2013. ${ }^{5}$ EFW is reported on a 0-10 scale, with larger values representing higher levels of economic freedom. While there are currently 159 countries in the EFW report, only need at least nine observations for our empirical approach. Thus we exclude from our data set any country that was not in the EFW annually beginning in 2005. The data are summarized in Table 1.

Table 1: Summary Statistics

\begin{tabular}{lrrrrr}
\hline Variable & Obs & Mean & St. Dev. & Min & Max \\
\hline rGDPpc & 1,755 & 11,440 & 15,976 & 135 & 86,129 \\
EFW & 1,589 & 6.8 & 0.9 & 2.9 & 9.2 \\
CE & 1,767 & -0.06 & 1.03 & -2.55 & 1.82 \\
CP & 1,767 & 48.82 & 28.71 & 0.00 & 100.00 \\
\hline
\end{tabular}

To get a better sense of the relationship between corruption, economic freedom, and national income we created scatterplots. The first thing one sees when looking scatterplots of corruption, economic freedom, and national income is how strongly correlated the variables are. Graph 1 presents a scatterplot of (the log of) real per capita national income and economic freedom (EFW). The two variables are strongly positively correlated: countries with more economic freedom and less governmental interference tend to have healthier richer economies. The negative correlation between national income and corruption is on display in Graph 2. There, we present two different measures of corruption: CE measures a country's index of corruption in absolute terms; CP measures a country’s corruption, relative to other countries.

\footnotetext{
${ }^{4}$ For more background on the EFW index and the literature that has used it, see Hall and Lawson (2014).

${ }^{5} \mathrm{~A}$ handful of countries are not in the data set in 2002. For example, Armenia's first year in the EFW is 2004. We have data on 118 countries starting annually in 2002 and by 2005 we have a total of 136 countries in the data set.
} 
Regardless of how it is measured, countries that are more corrupt tend to be much poorer. Finally, Graph 3 illustrates the correlation between corruption and economic freedom. The two variables are negatively related. That is, countries that are freer economically tend to be less corrupt.

\section{$4 \quad$ A More Detailed Look: Panel Vector Autoregressions}

One of the largest obstacles to resolving the question of causality is that all three variablesincome, economic freedom and corruption--are likely endogenous. Corruption decreases incomes; low incomes make it more likely that people engage in corruption. Economic freedom changes the returns to corruption; bureaucrats may decrease economic freedom to further exploit gains from corruption. Economic freedom directly increases national income; poor countries may require increased regulation because they have poorly developed markets (a dubious hypothesis, but a logically possible one). The causal arrows cannot be established using theory alone. These questions require empirical analysis.

We explore fully the reciprocal dynamics between economic freedom, corruption, and national income via a panel VAR model. A VAR model grows exponentially more complicated with each additional variable and lag that is added. Rather than reporting all the coefficients, we show the impulse response functions (IRFs) from each model. Before we can estimate a VAR, regardless of whether it is in panels or not, we must first verify that the data are stationary (integrated). Second, if they are integrated, we must verify that they are not cointegrated. If they are integrated, but not cointegrated, then a VAR model can be estimated in the first-differences. 
For each country in the dataset ( $\mathrm{N}=136)$, and for each variable involved (InrGDPpc, $E F W, C E$, and $C P$ ), we conducted an Augmented Dickey Fuller test of stationarity. ADF tests have been found to be sensitive to the number of lags included in the model. To circumvent this difficulty, we estimated the ADF tests for lags of 1,2 , and $3 .{ }^{6}$ We tested at the $5 \%$ level. Simple Type-I error would be expected to lead to $\mathrm{N}=7$ false positives $(136 * 0.05=6.8)$. In each instance, the number of countries that were found to be integrated far exceeded the number that would be expected from Type-I error. This was true, regardless of whether the model included a deterministic trend or not. For example, 16 (21) countries’ GDPs were found to be integrated, when tested against a 3-lag model with (without) a deterministic trend.

Having established that the variables are integrated, we must check whether they are cointegrated. A panel cointegration test was not computable given the unbalanced dataset and the small number of time periods in the dataset. ${ }^{7}$ Thus, we conduct a series of country-by-country tests. We calculated a set of Engle Granger (1987) tests for cointegration between InrGDPpc, $E F W$, and corruption (CE or $C P$ ). Only two countries showed any cointegration when corruption was measured by $C E$; only one, when corruption was measured by $C P$. Similar results held in a test including trend in the model: $4(C E)$ and $3(C P)$ countries showed cointegration. These numbers are far fewer than the 7 (6.8) countries that would be expected to show cointegration from Type-I error. Thus, we conclude that income, corruption, and economic freedom are not cointegrated. Thus, we do not need to estimate a Vector Error Correction Model (VECM), but rather a VAR.

\footnotetext{
${ }^{6}$ We estimated 3,288 ADF tests: 137 (the number of countries) x 4 (variables) x 2 (with and without trend) x 3 (the number of lags).

${ }^{7}$ As noted earlier, our data spans from 2002-2013 for 118 countries and a minimum of 2005-2013 for the remaining 17 countries in our unbalanced panel.
} 
The literature on VARs is fractured regarding estimating a VAR on integrated variables. Christopher Sims (1980) implies that differencing is not necessary and would throw away important information. Others, such as Peter Phillips (1998) disagree. He argues that IRFs from unrestricted VARs are inconsistent in the presence of unit roots. Given these problems of spurious regression, we focus on pVARs with differenced data.

How many lags should be included in the differenced pVAR models? We calculated the coefficient of determination for pVARS in differences with lags of one through four. Regardless of whether corruption was measured as $C E$ or $C E$, the coefficient of determination indicated that models with three lags were preferred.

In Graph 4, we show the IRFs from a pVAR in differences, where corruption is measured by $C E$, the absolute score on corruption. Graph 5 reports same for $C P$, the percentile rank of corruption. The two sets of IRFs show similar dynamics, only differing by their magnitudes. That is, the overall dynamics do not seem to depend on whether corruption is measured in absolute terms, or relative to the corruption of other countries. Both sets of estimates have eigenvalues inside the unit circle, indicating stability.

Graphs 4 and 5 show that an increase in (the change of) corruption (d.CE or d.CP) is not necessarily lingering: it tends to diminish over time. Moreover, this one-time increase in corruption has a negligible effect of economic freedom and in wealth accumulation. An increase in economic freedom, on the other hand, decreases corruption and increases per capita wealth accumulation. Finally, increases in wealth accumulation have no meaningful effect on corruption. Increases in wealth accumulation, however, are correlated with small yet statistically significant increases in economic freedom. In summary, economic freedom decreases corruption 
and improves the economy and these results hold regardless of whether corruption is absolute or relative.

Does the effect of corruption depend on whether the country is already over-regulated in terms of economic freedom? Are the proponents of the efficient corruption hypothesis such as Leff (1964), Huntington (1968), Shleifer and Vishny (1993) and Mauro (1995) correct? Is corruption a second-best escape-valve from over-burdensome restrictions on free trade? To answer these questions, we split our sample into two groups: countries that are more free than average $(E F W>6.8)$, and those that are less $(E F W<6.8)$ ? If the efficient corruption hypothesis is correct, then increases in corruption will decrease incomes in high-EFW countries, but will decrease incomes by less (or even raise them) in low-EFW countries.

To limit the proliferation of graphs, we restrict ourselves to estimating the model corruption measured only as $C E$. Graph 6a shows the IRF from a pVAR on economically free countries; Graph 6b repeats this for economically unfree countries. For both samples, the estimates pass the eigenvalue test for stability, with all eigenvalues inside the unit circle. In Graph 6a we see, once again, the same familiar dynamics between the three variables. The fact that shocks to d.CE have the same effect on d.InrGDPpc, regardless of whether we are looking at economically free or un-free countries, would seem to imply that the efficient corruption hypothesis is merely wishful thinking.

\section{Conclusion}

Income, economic freedom, and corruption interact in complex ways. All three variables are arguably endogenous. In this paper, we explicitly modeled the endogeneity using a panel VAR 
framework. The pVAR models we estimate are better able to model endogeneity than the singleequation panel data models that have been estimated elsewhere in the literature. That is, we are better able to capture the reciprocal causality between the variables. The pVAR models that we estimate provide evidence that corruption and regulations have a negative effect on national income.

Many previous studies in the literature acknowledge that the institutional setting helps determine income, but few examine the possibility that the setting determines the impact of corruption on income. Our final set of pVARs detects no evidence that corruption provides a safety valve from over-burdensome regulation. This is most likely because the prospect of illgotten gains creates the regulation in the first place. That is, the regulation is endogenous. The pVARs here reveal that, once this endogeneity is taken into account-that is, once we allow for the possibility that regulation increases corruption—we find that corruption makes countries poorer.

That said, it is hard to prove a negative. Panel VARs require estimating many coefficients, which decreases the available degrees of freedom, and makes detecting statistically small changes difficult. This is doubly true when the sample is split in half to test on high-EFW and low-EFW subsamples. Perhaps the effect exists, but is not detectible with the current amount of data. Once more data are collected, we might be able to confirm the efficient corruption hypothesis. But at this point, we argue that there is not enough evidence to support this optimistic hypothesis. For now: corruption is bad.

One hypothesis worth considering for future research is that weak economies, which usually are already struggling with corruption, have little to no efficiency to spare. In this case, a little bit of additional corruption would have a greater impact on those economies. This might be 
termed the "increasing marginal cost of corruption" hypothesis. This could be tested by splitting the sample into highly-corrupt, and negligibly-corrupt groups, and re-estimating the pVARs. If the hypothesis is correct, then a one unit increase in corruption would decrease incomes more in the highly-corrupt sample than in the negligibly corrupt countries. We leave this for future research. 
Graph 1: Economic Freedom and National Income

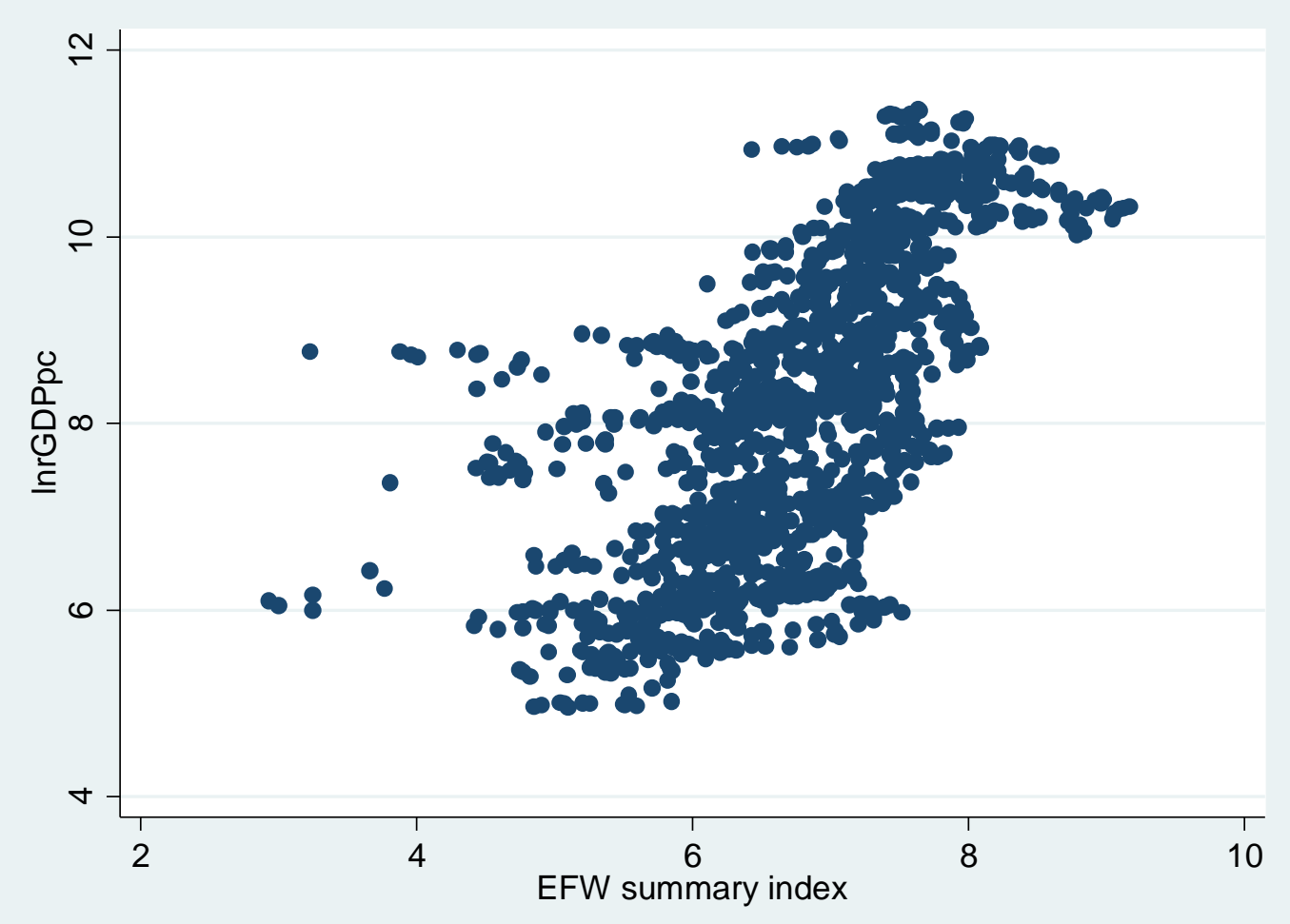

Graph 2: Corruption and National Income
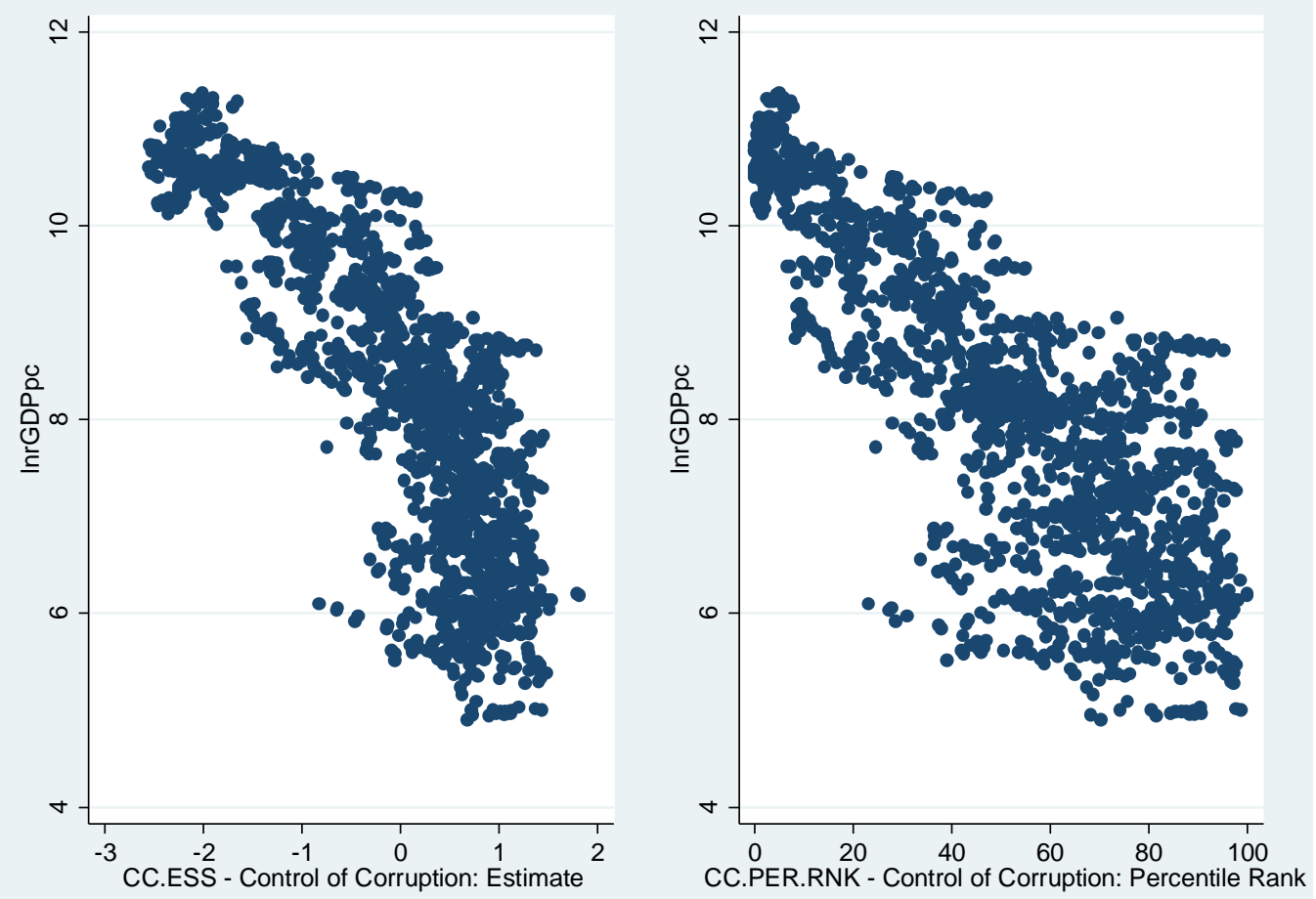
Graph 3: Economic Freedom and Corruption
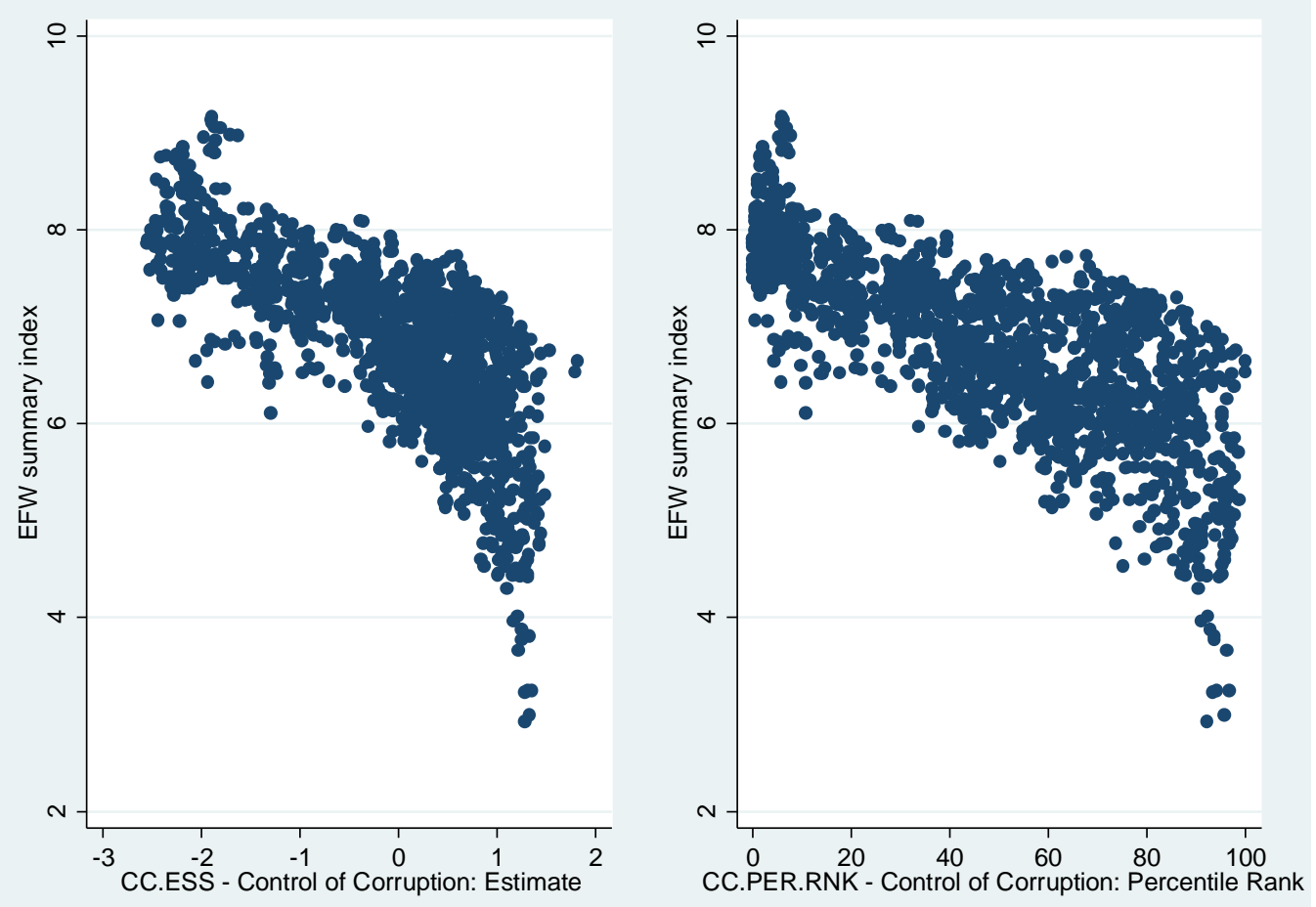
Graph 4: pvar dlnrGDPpc dEFW dCE, lags(3)
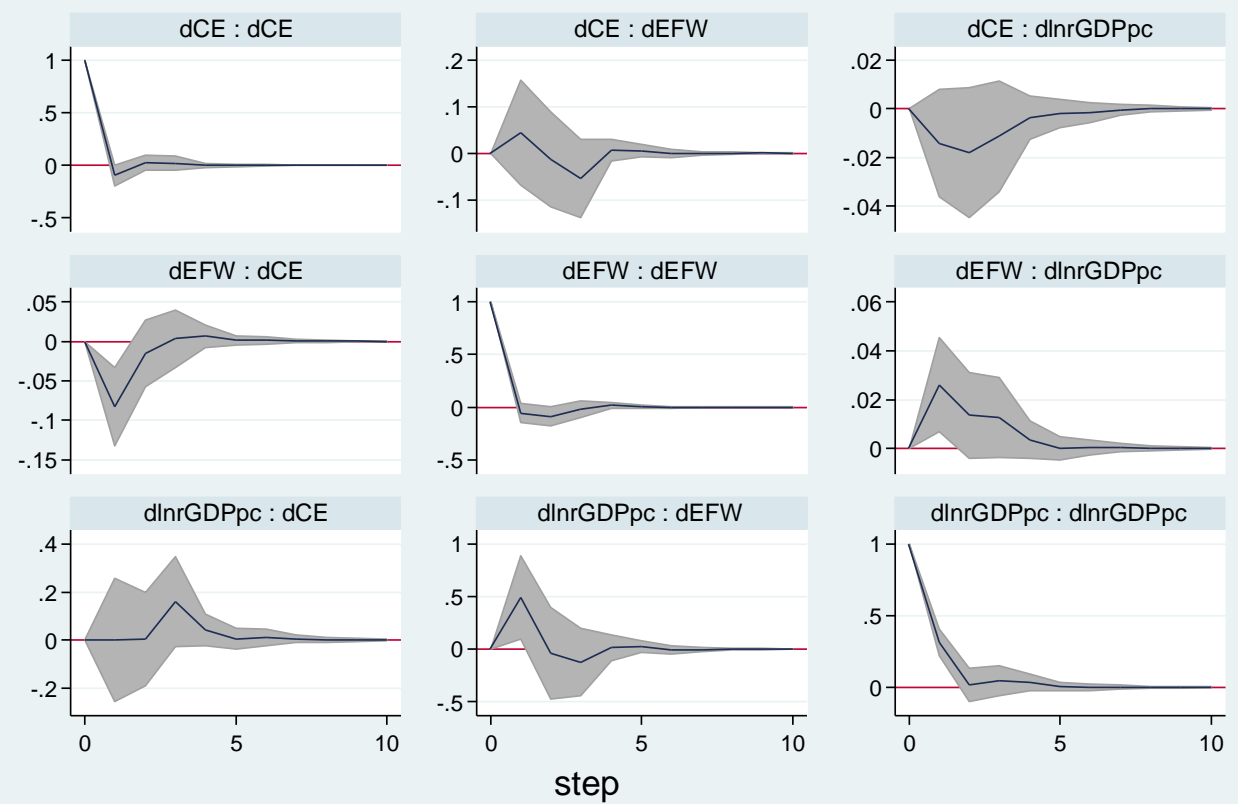

$95 \% \mathrm{Cl} \longrightarrow \mathrm{IRF}$

impulse : response

Graph 5: pvar dlnrGDPpc dEFW dCP, lags(3)
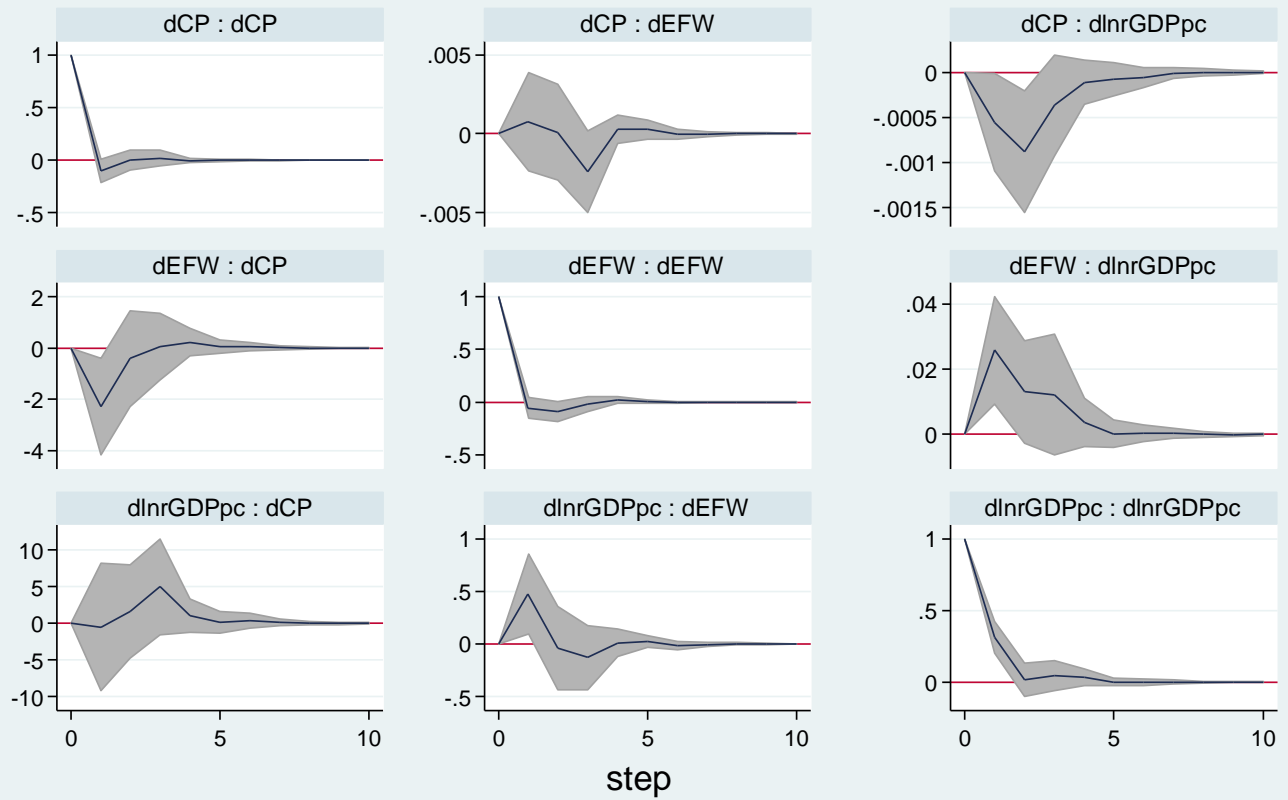

impulse : response 
Graph 6a: pvar dlnrGDPpc dEFW dCE if EFW>=6.802, lags(3)
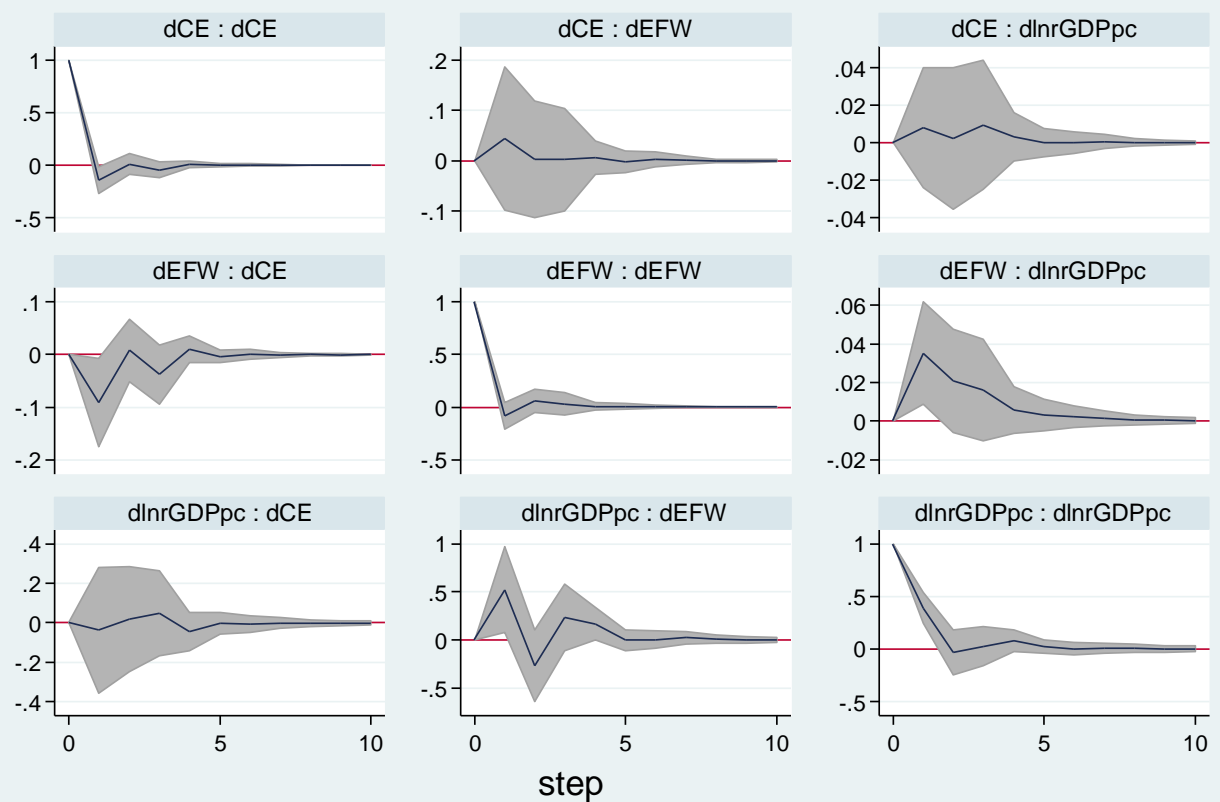

$95 \% \mathrm{Cl}$

IRF

impulse : response

Graph 6b: pvar dlnrGDPpc dEFW dCE if EFW<=6.802, lags(3)
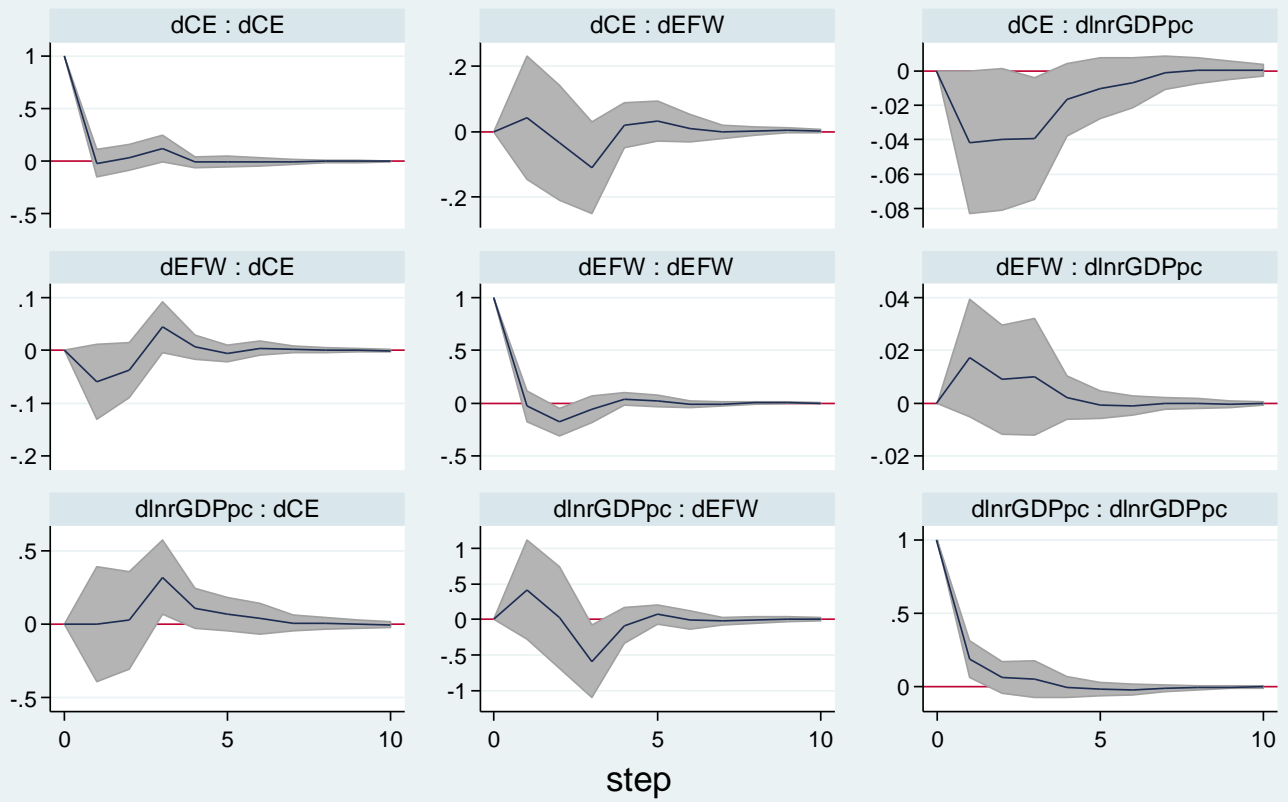

impulse : response 


\section{References}

Aixalá, José, and Gema Fabro. 2009. "Economic freedom, civil liberties, political rights and growth: A causality analysis.” Spanish Economic Review 11, no. 3: 165-178.

Banerjee, Abhijit, Sendhil Mullainathan, and Rema Hanna. 2012. “Corruption.” In The Handbook of Organizational Economics, Robert Gibbons and John Roberts, eds. Princeton, NJ: Princeton University Press, pp. 1109-1147.

Bardhan, Pranab. 1997. “Corruption and development: A review of the issue.” Journal of Economic Literature 34, no. 3: 1320-1346.

Beaulier, Scott, Bob Elder, Cheryl Han, and Joshua C. Hall. 2016. “An ordinal ranking of economic institutions.” Applied Economics 48, no. 26: 2482-2490.

Bjørnskov, Christian. 2012. “Can bribes buy protection against international competition?” Review of World Economics 148, no. 4: 751-775.

Bologna, Jamie. 2016. "The effect of informal employment and corruption on income levels in Brazil.” Journal of Comparative Economics 44, no. 3: 657-695.

Bologna, Jamie, and Joshua Hall. 2014. "Economic freedom research: Some comments and suggestions.” In Economic Freedom and Economic Education, Ideas and Influence of James Gwartney, Joshua Hall, ed. Beloit: Beloit College Press, pp. 123-135.

Campos, J. Edgardo, Donald Lien, and Sanjay Pradhan. 1999. “The impact of corruption on investment: Predictability matters.” World Development 27 no. 6: 1059-1067.

Choi, Jay Pil, and Marcel Thum. 2004. “The economics of repeated extortion.” Rand Journal of Economics 35, no. 2: 203-223.

Cuervo-Cazurra, Alvaro. 2006. “Who cares about corruption?” Journal of International Business Studies 37, no. 6: 807-822.

Dawson, John. 1998. "Institutions, investment, and growth: New cross-country and panel data evidence.” Economic Inquiry 36, no. 4: 603-619.

Egger, Peter, and Hannes Winner. 2005. "Evidence on corruption as an incentive for foreign direct investment.” European Journal of Political Economy 21, no. 4: 932-952.

Engle, Robert, and Clive Granger. 1987. "Co-integration and error correction: Representation, estimation and testing.” Econometrica 55, no. 2: 251-276.

Fisman, Raymond, and Jakob Svensson. 2007. "Are corruption and taxation really harmful to growth? Firm level evidence.” Journal of Development Economics 83, no. 1: 63-75. 
Goel, Rajeev K., and Michael A. Nelson. 2005. "Economic freedom versus political freedom: Cross-country influences on corruption.” Australian Economic Papers 44, no. 2: 121133.

Grossman, Gene, and Alan B. Krueger. 1993. "Environmental Impacts of a North American Free Trade Agreement.” In The Mexico-U.S. Free Trade Agreement, Peter Garber, ed. Cambridge, MA: MIT Press.

Graeff, Peter, and Guido Mehlkop. 2003. "The impact of economic freedom on corruption: Different patterns for rich and poor countries.” European Journal of Political Economy 19, no. 3: 605-620.

Gwartney, James, Robert Lawson, and Joshua Hall. 2016. Economic Freedom of the World: 2016 Annual Report. Vancouver: Fraser Institute.

Hall, Joshua. 2016. “Institutional convergence: Exit or voice?” Journal of Economics and Finance 40, no. 4: 829-840.

Hall, Joshua C., and Robert A. Lawson. 2014. "Economic freedom of the world: An accounting of the literature." Contemporary Economic Policy 32, no. 1: 1-19.

Harbaugh, William T., Arik Levinson, and David Wilson. 2002. Reexamining the empirical evidence for an environmental Kuznets curve. Review of Economics and Statistics 84, no. 3: 541-551.

Huntington, Samuel P. 1968. Political Order in Changing Societies. New Haven, CT: Yale University Press.

Kaufmann, Daniel. and Shang-Jin Wei. 1999. "Does 'grease money’ speed up the wheels of commerce?” National Bureau of Economic Research Working Paper No. 7093.

Kurer, Oskar. 1993. "Clientelism, corruption, and the allocation of resources.” Public Choice 77, no. 2: 259-273.

Leff, Nathaniel H. 1964. "Economic development through bureaucratic corruption.” American Behavioral Scientist 8, no. 3: 8-14.

March, Ray, Conrad Lyford, and Benjamin Powell. 2017. "Causes and barriers to increases in economic freedom.” International Review of Economics 64, no. 1: 87-103.

Mauro, Paolo. 1995. “Corruption and growth.” Quarterly Journal of Economics 110, no. 3: 681712.

Meon, Pierre-Guillaume, and Khalid Sekkat. 2005. "Does corruption grease or sand the wheels of growth?” Public Choice 122, no. 1/2: 69-97. 
Mo, Pak Hung. 2001. “Corruption and economic growth.” Journal of Comparative Economics 29, no. 1: 66-79.

Murphy, Kevin, Andrei Shleifer, and Robert Vishny. 1991. "The allocation of talent: Implications for growth.” Quarterly Journal of Economics 106, no. 2: 503-530.

Murphy, Kevin, Andrei Shleifer, and Robert Vishny. 1993. "Why is rent-seeking so costly to growth?” American Economic Review 83, no 12: 409-14.

Myrdal, Gunnar. 1968. Asian Drama. New York: Random House.

Phillips, Peter C. 1998. "Impulse response and forecast error variance asymptotics in nonstationary VARs.” Journal of Econometrics 83, no. 1: 21-56.

Pieroni, L. and G. D'Agostino. 2013. "Corruption and the effects of economic freedom." European Journal of Political Economy 29, no 2: 54-72.

Rode Martin, and Sebastian Coll. 2012. "Economic freedom and growth: Which policies matter the most?” Constitutional Political Economy 23, no. 2: 95-133.

Saha, Shrabani, Rukmani Gounder, and Jen-Je Su. 2009. "The interaction effect of economic freedom and democracy on corruption. A panel cross-country analysis.” Economics Letters 105, no. 2: 173-176.

Shen, Ce, and John B. Williamson. 2005. "Corruption, democracy, economic freedom, and state strength: A cross-national analysis.” International Journal of Comparative Sociology 46, no. 4: 327-345.

Sims, Christopher A. 1980. "Macroeconomics and reality.” Econometrica 48, no. 1: 1-48.

Treisman, Daniel. 2000. “The causes of corruption: A cross-national study.” Journal of Public Economics 76, no. 3: 399-457.

Shleifer, Andrei, and Robert Vishny. 1993. “Corruption.” Quarterly Journal of Economics 108,

Stern, David I. 2004. "The rise and fall of the environmental Kuznets curve.” World Development 32, no. 8: 1419-1439.

Svensson, Jakob. 2005. “Eight questions about corruption.” Journal of Economic Perspectives 19, no. 3: 19-42.

de Vaal, Albert, and Wouter Ebben. 2011. "Institutions and the relation between corruption and economic growth.” Review of Development Economics 15, no. 1: 108-123. 
Vega-Gordillo, Manuel, and Jose Alvarez-Arce. 2003. "Economic growth and freedom: A causality study.” Cato Journal 23, no. 2: 199-216

Wei, Shang-Jin. 2000. "How taxing is corruption on international investors?” Review of Economics and Statistics 82, no. 1: 1-11.

Wu, Wenbo, and Otto Davis. 1999. "The two freedoms, economic growth and development: An empirical study.” Public Choice 100, no. 1: 39-64.

Worldwide Governance Indicators. 2017. “Control of Corruption Documentation.” Online at: http://info.worldbank.org/governance/wgi/cc.pdf. Accessed 16 May. 